\title{
HIGH INTENSITY EXERCISE AND FLEXIBILITY OF THE LOWER LIMBS: DOSE-EFFECT STUDY
}

\section{EXERCÍCIO DE ALTA INTENSIDADE E FLEXIBILIDADE DE MEMBROS INFERIORES: ESTUDO DE DOSE-EFEITO}

\section{EJERCICIO DE ALTA INTENSIDAD Y LA FLEXIBILIDAD DE LAS EXTREMIDADES INFERIORES: ESTUDIO DE DOSIS-EFECTO}

\begin{abstract}
João Rafael Valentim-Silva (Educador Físico)

Marcelo Lentini Costa ${ }^{2}$

(Educador Físico)

Glauber Lameira de Oliveira ${ }^{3}$ (Educador Físico)

Talita Adão Perini de Oliveira (Educadora Física)

Mario Cezar de Souza Costa Conceição ${ }^{4}$ (Educador Físico) Estélio Henrique Martin Dantas ${ }^{5}$ (Educador Físico)
\end{abstract}

1. Universidade Federal de Rondônia, Faculdades Integradas de Goiás, Porto Velho, RO, Brasil. 2. Universidade Federal de Rondônia, Laboratório de Cineantropometria, Porto Velho, $\mathrm{RO}$, Brasil.

3. Laboratório de Biociência da Motricidade Humana (LABIMH), Rio de Janeiro, RJ, Brasil.

4. Secretaria Municipal de

Educação da Prefeitura do Rio de Janeiro, RJ, Brasil.

5. Universidade Federal do Estado do Rio de Janeiro (UNIRIO), Rio de Janeiro, RJ, Brasil.

\section{Correspondência:}

Rua Clara Nunes, 6231, Aponiã, Porto Velho, Rondônia, Brasil. 76824184. p.jrvalentim@gmail.com

\begin{abstract}
Introduction: Sports scientists have been studying the phenomenon involving different types of exercises and their influence on other activities. Stretching exercises have a negative influence on muscular strength and power output, as do high intensity or long duration cardiovascular training. Nevertheless, several studies have found the opposite to be true Nevertheless, few investigations have studied the opposite. Objective: To determine whether high intensity power exercise influences muscular flexibility in an acute manner. Methods: A sample of forty-three male and female young adults aged between 18 and 28 years, with a mean age of $22.88 \pm 3.04$ years, who have practiced physical activity for at least six months. To determine flexibility, the sit-and-reach test was used. For the high intensity training, a $45^{\circ}$ leg press was used. A 10-rep movement was performed at $85 \%$ of 1 RM, in both pre- and post-tests. Statistic analysis was conducted using the ANOVA and Scheffer's post-hoc tests, with a level of significance for differences of $\leq 0.05$. Results: Comparison of the pre- and post-tests proved to be statistically significant from the baseline from the fourth to the seventh repetitions. Conclusion: Strength exercises at 85\% of 1RM seem to significantly increase range of motion in an acute manner, and the growth of this range of motion has a dose-effect response.
\end{abstract}

Keywords: muscle strength; muscle stretching exercises; pliability

\section{RESUMO}

Introdução: Os cientistas do esporte veem estudando o fenômeno que envolve diferentes tipos de exercícios e sua influência sobre outras atividades. Os exercícios de alongamento têm influência negativa sobre a força e potência muscular, da mesma forma que o treinamento cardiovascular de longa duração ou alta intensidade. No entanto, poucas investigações têm estudado o oposto. Objetivo: Identificar se o exercício de alta intensidade tem influência sobre a flexibilidade muscular de forma aguda. Métodos: Amostra de quarenta e três jovens adultos do sexo masculino e do sexo feminino entre 18 e 28 anos de idade, com média de idade de 22,88 \pm 3,04 anos, praticantes de atividade física por pelo menos seis meses. Para verificar a flexibilidade, foi utilizado o teste de sentar e alcançar. Para o treinamento de alta intensidade, foi selecionada a pressão de pernas (leg press) em $45^{\circ}$. Foram realizadas 10 repetições a 85\% de 1 RM, tanto no pré quanto no pós-teste. A análise estatística foi realizada por ANOVA e testes post hoc de Scheffer, com nível de significância para diferenças $\leq 0,05$. Resultados: A comparação entre pré e pós-teste mostrou-se estatisticamente significante desde a linha de base, da quarta até a sétima repetição. Conclusão: Os exercícios de força a 85\% de 1 RM parecem aumentar significativamente a amplitude de movimento de forma aguda e o crescimento dessa amplitude de movimento tem resposta de dose-efeito.

Descritores: força muscular; exercícios de alongamento muscular; maleabilidade.

\section{RESUMEN}

Introducción: Los científicos del deporte están estudiando el fenómeno que consiste en diferentes tipos de ejercicio y su influencia en otras actividades. Los ejercicios de estiramiento tienen influencia negativa sobre la fuerza muscular y la potencia, al igual que el entrenamiento cardiovascular a largo plazo o de alta intensidad. Sin embargo, pocas investigaciones han estudiado lo contrario. Objetivo: Identificar si el ejercicio de alta intensidad influye en la flexibilidad muscular de manera aguda. Métodos: Muestra de cuarenta y tres hombres y mujeres jóvenes de ambos sexos de entre 18 y 28 años, con una edad media de 22,88 \pm 3,04 años, que practican actividad física durante al menos 6 meses. Para verificar la flexibilidad, se utilizó la prueba de sentarse y alcanzar. Para el entrenamiento de alta intensidad se seleccionó la prensa de piernas (leg press) en $45^{\circ}$. Se realizaron 10 repeticiones a $85 \%$ de 1 RM, tanto en pre y post-test. El análisis estadístico se realizó mediante análisis ANOVA y prueba post hoc de Scheffer, con nivel de significación de las diferencias <0,05. Resultados: La comparación entre el pre y post-test mostró una diferencia estadísticamente significativa respecto 
al valor basal, desde la cuarta hasta la séptima repetición. Conclusión: Los ejercicios de fuerza en el 85\% de 1 RM parecen aumentar significativamente el rango de movimiento de manera aguda y el crecimiento de este rango de movimiento tiene una respuesta de dosis-efecto.

Descriptores: fuerza muscular; ejercicios de estiramiento muscular; docilidad.

\section{INTRODUCTION}

Sports scientists have been studying the phenomenon involving different types of exercises and their influence in other activities. This method of physical training is called concurrent training. It is known, for example, that flexibility exercise can have negative influences on strength production $^{1-3}$ and muscular potency, as well as cardiovascular training.

Concurrent training for sports can be of great importance, bearing in mind that training can make the difference between the joy of winning or the frustration of loosing an Olympic competition. In gyms, its importance is not yet well known, although we know that muscle strength performance has influences on both medium and long-term results for people subjected to such training.

Flexibility training is a modality whose effects on muscle strength and power have been thoroughly researched ${ }^{1-9}$. Cardiovascular modalities such as running or cycling have also been extensively investigated ${ }^{4}$. Several investigations have shown that flexibility training can immediately damage the production of muscle strength and potency $y^{1,5,6,8,9}$. Consequently, this type of training can contribute negatively to performance in high-performance sports ${ }^{10}$. In addition, high-intensity or long-term cardiovascular training is a peripheral phenomenon, and therefore this exercise modality diminishes the muscle glycogen reserves $^{11,12}$. These glycogen reserves are the most significant source of fuel used in the vigorous contraction of muscles ${ }^{13-15}$.

However, the postulated hypothesis for this research is that high-intensity exercise has a positive influence on muscular flexibility because of its ability to facilitate movement or improve performance. So, the gap of knowledge is related with the fact that does not have in the literature references about this point.

Thinking about this, we hypostatize that the high intensity exercise can alter the muscle strength and could have a beneficial dose response.

Therefore, the aim of this study was to identify whether high intensity of strength training affects the dynamics of acute muscle flexibility.

\section{METHODS}

This study follows the rules and recommendations for research on human beings of the National Health Council and the rules of the Helsinki Convention from 1964 and revised at 2000. This paper was approved in Ethics Council of Human Research of Metropolitana College under protocol number of 156.919/2012.

\section{Sample Selection}

All participants freely volunteered to participate in this study after reading the terms of the study and then signing a consent form. A sample of forty-three young adults between 18 and 28 years of age with an average of $22.88+3.04$ years of age were selected in two gyms in Rio de Janeiro. None of them had a history of injuries, illnesses or impairments of the musculoskeletal articulate system that could influence the results.

Individuals were excluded from participating in the study if they could not meet the minimum score in the Wells bank that was used to measure flexibility of lower limbs.

For this experiment, the control and experimental group consisted of a single group of 20 individuals who fulfilled the previous criteria.

\section{Instruments}

The Wells Bank test was used as a way to measure the muscular flexibility in lower limbs specifically in the posterior muscle chain. The test consists of a small wooden apparatus with a metric scale on its surface. The individual sits on the floor with both legs fully extended and with the sole of the foot in one of the grooves, without making ballistic movements. The individual then extends their hands far as possible in order to measure the score.

In order to measure strength, the 1RM test was utilized. The test consists of performing a specific exercise with such a load that the individual can perform only one movement, going to concentric failure in the second movement. If the individual could complete the second movement, the maximum load was recalculated and the individual was retested after a five-minute break.

For the high intensity training, a $45^{\circ}$ leg press was used. The specific leg press was of the brand name, Physicus. This specific leg press accomplishes the simultaneous flexion of the hip, knee as well as dorsiflexion in the eccentric phase, and in the concentric phase there is an extension in the hip, knee and also plantar flexion. The machine consists in a backrest, a seat and a platform where weights are added and supports are provided for this purpose. This machinery is set up at a $45^{\circ}$ inclination.

\section{statistical analysis}

The data was collected in gyms on a normal day before the participants started their daily training without prior warm-up or any other activity that could influence the results. The 1RM test was accomplished on days prior to data collection.

For comparison, a sit-and-reach test before was performed every session in the $45^{\circ} \mathrm{leg}$ press. This data were considered base data.

The training session on the $45^{\circ}$ leg press was composed of ten repetitions performed in a rhythm of about one per second for the concentric and one per second for the eccentric phase. It is worth mentioning that the bending motion of the knee was performed until the approximate limit of $90^{\circ}$ was calculated with a goniometer.

On the same day as the 1RM test, participants were provided with a brief overview of the experimental protocol.

A five-minute break between base data collection and the $45^{\circ} \mathrm{leg}$ press session was provided with the objective of minimizing the potential influence that one individual's results may have on the results of other participants on the sit-and-reach Wells Bank test. This break also provided time for data comparison.

All times was did five minutes after the previous and immediately before the $45^{\circ} \mathrm{leg}$ the wells bank test was applied for to measure the muscular flexibility.

\section{Experimental protocol}

The training protocol consisted of the following sequence:

- sit-and-reach test;

- Five minutes recovery;

- Session of ten repetitions at 85\% of 1RM, immediately followed by a second sit-and-reach test. This was did for seven times. 
The statistical analysis was accomplished utilizing an ANOVA analysis of variance with Scheffer's post-hoc and the significant differences were set at $\leq 0.05$. The abnormality was calculated using Shpiro-Wilks test and the size of the group was calculated in 7 subjects for the test with 0.99 of power and significance of 0.05 .

\section{RESULTS}

Table 1 shows the means and standard deviations relating to the pre and post test. Is evident that the power exercise can grow the stretching from the pre-test to post-test from the first moment until the seventh, showing that has an effect dependent of the dose.

Table 1. Mean and standard deviation and significance of ANOVA ONE-WAY with significance of 0.05 to the seven times of data.

\begin{tabular}{c|c|c|c|c|c|c|c|c}
\hline & & Baseline & Post 1 & Post 2 & Post 3 & Post 4 & Post 5 & Post 6 \\
\cline { 2 - 9 } $\begin{array}{c}\text { Lower } \\
\text { Limb }\end{array}$ & Mean (cm) & 18.27 & 20.13 & 21.79 & 23.27 & 24.71 & 26.11 & 27.53 \\
\cline { 2 - 9 } Stretching & S.D. & \pm 9.31 & \pm 9.31 & \pm 9.3 & \pm 9.36 & \pm 9.43 & \pm 9.3 & \pm 9.3 \\
\cline { 2 - 9 } & $\begin{array}{c}\text { Significance } \\
\text { to Baseline }\end{array}$ & & $P>0.05$ & $P>0.05$ & $P>0.05$ & $P<0.05$ & $P<0.01$ & $P<0.01$ \\
\hline
\end{tabular}

\section{DISCUSSION}

The objective of this study was to examine whether high-intensity exercise has affect upon the muscle flexibility and their dose-effect. The postulated hypothesis for this investigation was that high-intensity exercise would have a positive effect on muscle flexibility and the dose could have differential effect on the same variable.

The effects of different physical exercises in other physical modalities have been well documented by many researcher ${ }^{1-10,13,14,16-18}$, but even so, there are still gaps in the knowledge that involves concurrent training; such has the effect of dose and response and the frequency and the chronic effect of some exercises in other modalities.

The flexibility exercise is often used as a muscle warm-up exercise or as preparation for an activity and, therefore, is conducted in periods before the tests. It is known that this strategy can significantly alter an athlete's performance in a competition suggesting that the individual needs to be concerned with the warm-up techniques utilized so that their warm-up routine does not compromise their performance.

But nevertheless, there are not many reports of investigations on the reverse path. In other words, it is not known if high-intensity exercise causes acute changes in range of motion.

Several investigations have verified the effects of flexibility exercises in strength $1-3,5,6,8,9$ potency $y^{2,717,19,20}$, and in races of short duration and high intensity ${ }^{4,20}$.

It has been postulated that flexibility exercises as a warm-up strategy may be harmful if poorly scaled in volume or intensity as they can inadvertently turn off the nervous system switch involved in the proprioceptive system and therefore deadening the nerve impulses sent to muscles ${ }^{18}$

However, investigations of concurrent training have always followed the direction of identifying the influence of different modes of exercises on muscle strength and potency, but, beyond these impacts, concurrent training has not been well explored. Perhaps this is a result of the fact that the vast majority of athletic modalities are dependent on strength and potency, or at least on the ability the control to this force in order to increase the precision of movement. However, upon first analysis, it is not true to argue that most of the modalities are dependent on flexibility.

The data from this study demonstrate that one session of $85 \%$ of $1 \mathrm{RM}$ increases the range of motion after ten repetitions in an acute manner.

In a study where the effect of stretching was investigated alone, stretching over three sessions of four repetitions at 90\% of 1RM and just three sessions of four repetitions at 90\% 1RM on the vertical jump, showed that the stretching exercise had a deleterious effect on performance ${ }^{2}$. The same effect caused the high intensity exercise to allow greater range of motion after an exercise session.

The result of a study aimed at comparing four different stretching protocols on the performance of the short duration race $(20 \mathrm{~m})$, all significantly increased the time it had taken to travel the same distance, showing again that flexibility exercise decreases athletic performance. Consequently, this evidence shows how, once again, flexibility exercises can negatively impact athletic performance by making it impossible to produce the same amount of potency that was possible before passing through a session of this kind of exercise ${ }^{4}$.

The data found in this study show a decrease in muscle tone. Muscle tone is the property that the musculature needs in order to maintain both a maximum level of contraction as well maintain complete relaxation, voluntarily ${ }^{21}$.

On the one hand, the muscular tone is inversely proportional to flexibility. This means that the higher muscular tone is, the lower is the articular angle. On the other hand, the less nerve impulses that are able to reach the muscle, the main cause of a decrease in muscle tone, the less muscle strength is observed.

Bearing in mind that muscle power is a product of strength times the speed at which a body segment moves, it is possible to assert that stretching decreased the potency of the muscles involved in the movement.

This decrease in strength is attributed to a proprioceptive neural process that involves the Golgi tendon organ ${ }^{18}$. This organelle of muscular tendons is stimulated by vigorous contraction stress generated the flood the brain with nerve impulses that then stimulate muscle relaxation so that these tensions will not reach the same level again ${ }^{18}$. It is estimated that the stimulus is a protector of the musculoskeletal system.

The data found in this study clearly show evidence of muscular relaxation and a decrease in the tone and strength afforded by repeated muscular contractions with high intensity.

There is strong evidence that show how contractions can increase muscle relaxation. One technique is called proprioceptive muscular facilitation (PNF). This procedure involves the stretching of the musculature until a point of discomfort followed by a strong static muscular contraction for a minimum of fifteen seconds. This process gently increases the muscular amplitude which suggests a relaxation in response to the generated PNF tension ${ }^{20}$.

In sum, many authors have investigated the effect of flexibility on different muscular valences as strength and potency on different athletic modes such as running and jumping, but the reverse path has never been investigated; in other words, if high-intensity exercise could have any effect on muscular flexibility.

\section{CONCLUSION}

The present study investigated the acute effect of a high-intensity exercise session on the range of motion for lower limbs.

This study showed that power exercises are capable of modifying the stretching of muscle, however, studies that investigate the inverse is common.

According to data from this study, strength exercises at $85 \%$ of 1RM appear to significantly increase the range of motion in an acute manner, therefore, these exercises can contribute to an increase in muscle flexibility.

All authors have declared there is not any potential conflict of interests concerning this article. 
AUTORES' CONTRIBUTIONS: Each author contributed individually and significantly to the development of the manuscript. JRVS (0000-0002-9346-5389)* MLC (00000001-9943-3313)*, GLO (0000-0003-4959-5298)* and TAPO (0000-0003-4507-1956)* participated in all stages, from conception of scientific idea, selection and various evaluations, scientific writing, processing, interpretation and discussion of the data, corrections and approval of the final text. MCSCC (0000-0003-4545-0892)* and EHMD (0000-0003-0981-8020** participated in the scientific idea conception, scientific writing, interpretation and discussion of the data, corrections and approval of the final text by co- advisor and the advisor respectively. All authors contributed to the intellectual concept of the study. *Número ORCID (Open Researcher and Contributor ID).

\section{REFERENCES}

1. Bacurau RF, Monteiro GA, Ugrinowitsch C, Tricoli V, Cabral LF, Aoki MS. Acute effect of a ballistic and a static stretching exercise bout on flexibility and maximal strength. J Strength Cond Res. 2009;23(1):304-8

2. González-Ravé JM, Machado L, Navarro-Valdivielso F, Vilas-Boas JP. Acute effects of heavy-load exercises, stretching exercises, and heavy-load plus stretching exercises on squat jump and countermovement jump performance. J Strength Cond Res. 2009;23(2):472-9.

3. LaRoche DP, Lussier MV, Roy SJ. Chronic stretching and voluntary muscle force. J Strength Cond Res. 2008;22(2):589-96

4. Gergley JC. Acute effect of passive static stretching on lower-body strength in moderately trained men. J Strength Cond Res. 2013;27(4):973-7.

5. Herda TJ, Ryan ED, Smith AE, Walter AA, Bemben MG, Stout JR, et al. Acute effects of passive stretching vs vibration on the neuromuscular function of the plantar flexors. Scand J Med Sci Sports. 2009;19(5):703-13.

6. Jaggers JR, Swank AM, Frost KL, Lee CD. The acute effects of dynamic and ballistic stretching on vertical jump height, force, and power. J Strength Cond Res. 2008;22(6):1844-9.

7. Robbins JW, Scheuermann BW. Varying amounts of acute static stretching and its effect on vertical jump performance. J Strength Cond Res. 2008;22(3):781-6.

8. Ryan ED, Beck TW, Herda TJ, Hull HR, Hartman MJ, Stout JR, et al. Do practical durations of stretching alter muscle strength? A dose-response study. Med Sci Sports Exerc. 2008;40(8):1529-37.

9. Samuel MN, Holcomb WR, Guadagnoli MA, Rubley MD, Wallmann H. Acute effects of static and ballistic stretching on measures of strength and power. J Strength Cond Res. 2008;22(5):1422-8.

10. Place N, Blum Y, Armand S, Maffiuletti NA, Behm DG. Effects of a short proprioceptive neuromuscular facilitation stretching bout on quadriceps neuromuscular function, flexibility, and vertical jump performance. J Strength Cond Res. 2013;27(2):463-70.

11. Izquierdo M, González-Izal M, Navarro-Amezqueta I, Calbet JA, Ibañez J, Malanda A, et al. Effects of strength training on muscle fatigue mapping from surface EMG and blood metabolites. Med Sc Sports Exerc. 2011;43(2):303-11.

12. Lacombe VA, Hinchcliff KW, Geor RJ, Baskin CR. Muscle glycogen depletion and subsequent replenishment affect anaerobic capacity of horses. J Appl Physiol (1985). 2001;91(4):1782-90.

13. Busso T, Chatagnon M. Modelling of aerobic and anaerobic energy production in middle-distance running. Eur J Appl Physiol. 2006;97(6):745-54.

14. Jeukendrup AE, McLaughlin J. Carbohydrate ingestion during exercise: effects on performance, training adaptations and trainability of the gut. Nestle Nutr Inst Workshop Ser. 2011;69:1-12.

15. Kadaja L, Eimre M, Paju K, Roosimaa M, Põdramägi T, Kaasik P, et al. Impaired oxidative phosphorylation in overtrained rat myocardium. Exp Clin Cardiol. 2010;15(4):e116-27.

16. Babault N, Kouassi BY, Desbrosses K. Acute effects of 15 min static or contract-relax stretching modalities on plantar flexors neuromuscular properties. J Sci Med Sport. 2010;13(2):247-52.

17. Cramer JT, Beck TW, Housh TJ, Massey LL, Marek SM, Danglemeier S, et al.Acute effects of static stretching on characteristics of the isokinetic angle - torque relationship, surface electromyography and mechanomyography. J Sports Sci. 2007;25(6):687-98.

18. Mileusnic MP, Loeb GE. Force estimation from ensembles of Golgi tendon organs. J Neural Eng 2009;6(3):036001

19. Alpkaya U, Koceja D. The effects of acute static stretching on reaction time and force. J Sports Med Phys Fitness. $2007 ; 47(2): 147-50$

20. La Torre A, Castagna C, Gervasoni E, Cè E, Rampichini S, Ferrarin M, et al. Acute effects of static stretching on squat jump performance at different knee starting angles. J Strength Cond Res. 2010 Mar;24(3):687-94

21. Schyns F, Paul L, Finlay K, Ferguson C, Noble E. Vibration therapy in multiple sclerosis: a pilot study exploring its effects on tone, muscle force,sensation and functional performance. Clin Rehabil. 2009;23(9):771-81. 